\title{
NARRATIVAS BILÍNGUES DE MÃES E FILHOS DE TRÊS ANOS: ESTILO, PAPÉIS INTERACIONAIS E USO DAS LÍNGUAS
}

\author{
NARRATIVAS BILINGUES DE MADRES E HIJOS DE TRES AÑOS: ESTILO, PAPELES INTERACCIONALES \\ Y USO DE LAS LENGUAS
}

BILINGUAL NARRATIVES FROM MOTHERS AND THREE-YEAR-OLD CHILDREN: STYLE, INTERACTION ROLES AND LANGUAGE USE

\author{
Bernardo Kolling Limberger* \\ Ana Maria Stahl Zilles** \\ Universidade do Vale do Rio dos Sinos - UNISINOS, São Leopoldo, BR
}

\begin{abstract}
RESUMO: Este artigo visa analisar os estilos narrativos e os papéis interacionais de duas díades mãe-filho de três anos enquanto compartilham um livro de gravuras. As díades são bilíngues e residem na comunidade de Santa Maria do Herval (RS). Para identificar os estilos narrativos e os papéis desempenhados pela mãe e pela criança, analisa-se a contribuição de cada um para o desenrolar da história. Além disso, analisa-se qualitativamente o uso das línguas em jogo. Em uma interação predominantemente em alemão, constatou-se a adoção pela mãe do estilo elaborativo. Em outra interação em português com alternância de códigos para o alemão, a mãe adotou o estilo pouco elaborativo. Quanto aos papéis interacionais, as crianças foram estimuladas por suas mães a adotar o papel de co-narradoras da história. Isso se aproxima dos resultados das díades com crianças da mesma idade que interagiram em português na mesma comunidade.

PALAVRAS-CHAVE: narrativas; hunsrückisch; bilinguismo; estilos narrativos; papéis interacionais.
\end{abstract}

RESUMEN: En este artículo se objetiva analizar los estilos narrativos y los papeles interactivos de dos parejas madre-hijo de tres años mientras comparten un libro de imágenes. Las parejas son bilingües y viven en la comunidad de Santa Maria do Herval (RS). Para identificar los estilos narrativos y los papeles desarrollados por la madre y por el niño, analizase la contribución de cada uno de ellos para el desarrollo de la historia. Además, analizase cualitativamente el uso de las lenguas en juego. En una interacción predominantemente en alemán, se observó que la adopción por la madre del estilo elaborativo. En otra interacción en portugués con alternancia de códigos para el alemán, la madre adoptó el estilo poco elaborativo. Cuanto a los papeles interactivos, los niños fueron estimulados por sus madres a adoptar el papel de co-narradores de la historia. Eso se acerca de los resultados de las parejas con niños de la misma edad que interactuaron en portugués en la misma comunidad.

PALABRAS-CLAVE: narrativas; Hunsrückisch; bilingüismo; estilos narrativos; papeles interactivos.

ABSTRACT: This paper aims to analyze the narrative styles and the interaction roles while two dyads (each constituted by the mother and a three-year-old child) share a picture book. The dyads are bilingual and live in Santa Maria do Herval (RS, Brazil). To identify the narrative styles and the roles played by mother and child, we analyze the contribution of each one to the progress of the history. In addition, we analyze qualitatively the use of the languages. In an interaction predominantly in German, it was noted the adoption by the mother of elaborative style. In another interaction, the mother took the low elaborative style. Regarding the roles in interaction, children were encouraged by their mothers to adopt the role of co-narrators of the story. This approximates from the results of the dyads with the same age that interacted in Portuguese in the same community.

KEYWORDS: narratives; Hunsrückisch; bilingualism; narrative styles; interactional roles.

\section{INTRODUÇÃO}

As narrativas estão presentes em casa, na escola, no ambiente de trabalho, em diversos âmbitos e contextos, desde os mais espontâneos até os mais institucionais. Bastos (2005, p. 74) postula que estudar as narrativas e seus participantes é uma forma de compreender a vida em sociedade, uma vez que as narrativas são contextos em que valores, costumes e a cultura de uma determinada comunidade são constituídos e preservados (BRUNER, 2001, p. $\mathrm{x}^{1}$ ). Como expõe Melzi (2000, p. 154), é comum as histórias serem contadas em casa com o intuito dos pais de ensinar algo a seus filhos. Além disso, as práticas

\footnotetext{
* Mestrando em Letras (Linguística) da PUCRS (bolsista CAPES). Graduado em Letras Português/Alemão pela Unisinos (2008), onde foi bolsista de iniciação científica da FAPERGS. Email: bernardo_k1@yahoo.com.br.

** Doutora em Letras (Linguística Aplicada) pela Pontifícia Universidade Católica do Rio Grande do Sul (1992). Atualmente, é professora do Programa de Pós-graduação em Linguística Aplicada da Unisinos. Email: anazil@unisinos.br.

${ }^{1}$ Na introdução do livro “A Cultura da Educação”, a enumeração das páginas é com algarismos romanos.
} 
conversacionais entre um adulto e seu filho, além de ensinarem valores, costumes e a cultura da comunidade (BRUNER, 2001; MELZI, 2000), promovem o desenvolvimento do discurso narrativo (PERRONI, 1992) e têm, segundo Haden (2003, p. 49), impactos no desenvolvimento do modelo de memória autobiográfica.

Diante dessa perspectiva, um evento narrativo bilíngue - a contação de uma história baseada no livro de gravuras "Frog, where are you?" (MAYER, 1969) em português e o Hunsrückisch - é o foco de estudo neste trabalho. Em Santa Maria do Herval (RS), em boa parte das famílias visitadas pela equipe do projeto de pesquisa ${ }^{2}$, pais e mães utilizam, para conversar entre si e com seus filhos, o português e uma variedade do alemão denominada Hunsrückisch. Conforme Altenhofen (1996), trata-se de uma variedade suprarregional do alemão, falada principalmente no sul do Brasil. Essa variedade se fundamenta num contínuo dialetal formado pelos dialetos trazidos pelos imigrantes alemães, a partir de 1824 (ALTENHOFEN; FREY, 2006).

Os dados aqui analisados foram obtidos com a colaboração de duas díades mãe-filho de três anos. O número limitado de participantes se deve à intenção de apresentar uma análise detalhada e predominantemente qualitativa, fornecendo exemplos de práticas familiares neste contex to bilíngue. A equipe do projeto visitou as famílias, realizou entrevistas, fez observação participante e redigiu diários de campo, procurando favorecer também a visão dos participantes. O evento narrativo entre mãe e filho foi gravado em áudio e em vídeo e, por fim, os membros da família assistiram ao vídeo, compartilhando as suas impressões.

De modo geral, o Hunsrückisch é considerado apenas como variedade de interação cotidiana exclusivamente oral. Neste trabalho, mostramos que seu uso também está associado a evento de letramento baseado em livro de gravuras, aproximando esta variedade de funções em geral associadas à escrita. Além disso, ao dar visibilidade ao uso dessa variedade de alemão, valorizam-se, também, as identidades dos respectivos falantes, oferecendo-se um singelo panorama do que é feito nesse tipo de evento com crianças pré-escolares dessa comunidade bilíngue.

O objetivo deste trabalho é analisar a co-construção de narrativas por duas díades mãe e filho, falantes de Hunsrückisch e português ${ }^{3}$. Para tanto, analisam-se os estilos narrativos e os papéis interacionais adotados tanto pela mãe quanto pela criança. Não buscamos traçar padrões da narrativa bilíngue, mas dar maior visibilidade a tal prática em nosso meio, sob uma perspectiva sociolinguística.

O artigo está estruturado da seguinte forma: após a introdução, focalizamos os pressupostos teóricos que adotamos para analisar as narrativas. A seção seguinte se dedica à explanação da metodologia. Na sequência, apresentamos os resultados da análise e, finalmente, as considerações finais que essa análise nos permite.

\section{A NARRATIVA}

Pesquisas das mais diversas áreas têm se interessado pelo estudo das narrativas orais. Bastos (2005, p. 70) explica que o interesse passou do estudo exclusivo da estrutura da narrativa para o estudo da razão de as narrativas estarem presentes em nossas vidas, do significado de contá-las e das ações de quem as conta ou as ouve.

Inicialmente apresentamos alguns fundamentos teóricos que caracterizam as narrativas orais dirigidas às e produzidas pelas crianças. Apresentamos pressupostos teóricos sobre (1) a aquisição da linguagem e do discurso narrativo, bem como a aquisição bilíngue da linguagem; (2) a narrativa e suas relações com o letramento e com a cultura; e (3) fatores que são considerados ao (ensinar a) contar uma história e estilos narrativos adotados pelas mães, bem como papéis interacionais desempenhados pelos participantes. Esse é o suporte para analisar os dados gerados com a colaboração de famílias de Santa Maria do Herval (SMH).

\footnotetext{
2 Trata-se do projeto Diferenças socioculturais e linguísticas na interação entre mães e filhos em idade pré-escolar: a co-construção de narrativas por falantes monolíngues e bilíngues, coordenado por Ana M. S. Zilles em parceria com Gigliana Melzi (New York University). O projeto teve aprovação do Comitê de Ética em Pesquisa da Unisinos, recebendo como resolução o número 027/2005. Este artigo está inserido no referido projeto.

${ }^{3}$ Agradecemos às díades que participaram deste estudo, pela acolhida em suas casas e colaboração.
} 


\subsection{A aquisição do discurso narrativo bilíngue}

O presente estudo é fundamentado na perspectiva sociointeracional de aquisição da linguagem, segundo a qual a criança adquire a linguagem por meio da interação com outras pessoas dentro da sociedade. Em outras palavras, "a linguagem é adquirida na interação criança-interlocutor básico, através de processos dialógicos específicos e explicativos da construção conjunta pelo adulto e pela criança de objetos comunicativos ou partilhados" (LEMOS, 1983, p. 3 apud PERRONI, 1992, p. 15). São levados em conta, então, fatores sociais, comunicativos e culturais para a aquisição da linguagem.

Nesse sentido, entendemos que a linguagem é adquirida através de um processo de co-construção de sequências conversacionais pelo adulto e pela criança. Assim, a narrativa consiste realmente de uma forma de ação conjunta (CLARK, 2000, p. 49). Isso acontece porque, como explicam Jacoby e Ochs (1995, p. 171), toda interação é co-construída entre os seus participantes. $\mathrm{O}$ uso do prefixo co- em co-construção procura recobrir uma série de processos interacionais, incluindo colaboração, cooperação e coordenação. Conforme explica Scarpa (2001, p. 217), a criança e o adulto se engajam em ações que patenteiam instâncias de atenção partilhada e ação conjunta, ações que se relacionam com o andaimento (scaffolding). Wood, Bruner e Ross (1976, p. 89) cunharam o termo mencionado, mas empregaram também o termo tutoria - modos de agir pelos quais um adulto ou uma pessoa mais experiente auxilia alguém que é menos experiente. Os autores tiveram por base o conhecido conceito de zona de desenvolvimento proximal (ZDP), proposto por Vygotsky (1989), que é descrito como

a distância entre o nível de desenvolvimento real da criança, que se costuma determinar através da solução independente de problemas, e o nível de desenvolvimento potencial, determinado através da solução de problemas sob orientação de um adulto ou em colaboração com companheiros mais capazes (VYGOTSKY, 1989, p. 97).

A adoção de comportamentos que podem ser descritos como andaimento é muito útil, no caso, para as crianças, uma vez que tais comportamentos favorecem e facilitam que elas aprendam. Uma mãe (ou qualquer outro interlocutor mais experiente), ao conversar com a criança, pode auxiliá-la, de modo a fornecer andaimes (suportes). Depois, os andaimes vão sendo "retirados", à medida que a criança adquire as habilidades e realiza com autonomia as ações pretendidas.

Zilles e Knecht (2009, p. 45) analisaram o andaimento fornecido por uma mãe no evento narrativo com a sua filha de três anos enquanto compartilharam o livro de gravuras que também é adotado nesta pesquisa. A díade era da mesma comunidade (SMH), mas não era bilíngue. As autoras constataram que houve criação conjunta e andaimento em aspectos como a) a interpretação das gravuras do livro; b) os papéis próprios à atividade de narrar (narrador, ouvinte, co-narrador); c) as identidades dos leitores, de mãe e de filha; d) o modo de observar as gravuras e descrevê-las; e) as habilidades de narrar; f) a visão de mundo e os valores compartilhados; e g) as emoções. Desse modo, o andaimento não se restringe a aspectos linguísticos estrito senso, abrangendo também aspectos discursivos, cognitivos e culturais, que são compartilhados entre mães e filhos.

Com relação ao discurso narrativo de crianças bilíngues, os trabalhos analisados por Iluz-Cohen e Walters (2012, p. 60) mostram uma interdependência das habilidades narrativas, principalmente da estrutura da narrativa, entre as línguas faladas pelas crianças. Dessa forma, habilidades narrativas em uma língua parecem se beneficiar da sua aquisição em outra língua, ao passo que as habilidades lexicais e morfossintáticas são menos predispostas à transferência de uma língua para outra. Há, portanto, diferenças maiores com relação ao vocabulário, mas não com relação à estrutura. Não encontramos, contudo, nesse artigo e em outros, investigações a respeito do estilo narrativo da mãe bilíngue ao contar histórias para seus filhos.

Altenhofen (2002, p. 8) apresenta especificidades da fala bilíngue do adulto ao interagir com crianças. No caso do Hunsrückisch, o autor constatou o uso de baby talk, a fala modificada de adultos dirigida a crianças, segundo a definição apresentada por Schnack (2005). Esse uso é constituído principalmente por abundância de diminutivos e entoação característica, os quais enaltecem a carga de afetividade da interação. $\mathrm{O}$ Hunsrückisch apresenta um estilo particular de baby talk que integra elementos do alemão à base de língua portuguesa (por exemplo: Mach Sentache! literalmente 'Faz sentazinho!'). 
Uma característica que está bastante presente nas interações entre quaisquer falantes bilíngues é a alternância de código (code switching). Num sentido geral, a alternância de código se configura pela "passagem do uso de uma variedade linguística para outra que os falantes de alguma forma percebem como distintas" (GARCEZ; OSTERMANN, 2002, p. 258). Conforme explica Breunig (2005, p. 67), essa alternância não deve ser julgada como decadência linguística, pois ela não é um fenômeno isolado, mas elemento central do discurso bilíngue. Esse fenômeno não se restringe à falta de conhecimento ou entendimento de uma das línguas em jogo, pois envolve muitos aspectos de ordens diversas, como o tópico tratado e a carga emocional ou afetiva maior que uma das línguas pode ter em relação à outra (PARADIS, GENESSE; CARGO, 2011, p. 99).

Feitas essas considerações a respeito da aquisição bilíngue da linguagem, passamos agora a refletir sobre características específicas do foco desse trabalho - a narrativa, que aqui estará sempre associada ao letramento.

\subsection{A narrativa como evento de letramento culturalmente situado}

Como é possível observar em várias comunidades (inclusive na comunidade alvo do estudo), pais e outros membros da família se engajam em eventos de letramento com crianças em idade pré-escolar. São exemplos disso a contação de uma história a partir de um livro de gravuras e a leitura conjunta de um livro infantil.

Segundo Heath (2001), aprender as técnicas de leitura, mas não participar de eventos sociais em que a leitura e a escrita sejam elementos constitutivos, não configura letramento em sua concepção sociocultural. No letramento, o principal é, então, participar de eventos nos quais a leitura e a escrita façam sentido.

A contação de uma história com base num livro de gravuras é um evento de letramento, e, além disso, um evento social. De modo geral, os eventos sociais se desenvolvem, conforme Garcez e Ostermann (2002), ao redor de um tópico ou, no máximo, de um âmbito limitado de tópicos e se distinguem por suas estruturas sequenciais. Eles são marcados por rotinas de abertura e fechamento estereotipadas e, portanto, reconhecíveis ${ }^{4}$.

O livro de gravuras, apesar de não ter texto escrito, é um material fundamental para que o evento narrativo ocorra, neste estudo. Ademais, por haver uma constância na sequência de gravuras, o uso desse livro oferece algumas facilidades na comparação entre as histórias que mães e crianças contam. Por outro lado, é importante ressaltar que, na comunidade alvo do estudo, os livros são geralmente associados à escrita e, consequentemente, ao uso de português, já que o Hunsrückisch é usado e percebido como sendo uma língua somente oral. Os participantes conversam a partir desse material, de acordo com regras social e culturalmente estabelecidas. Por esse motivo, segundo Heath (2001, p. 340), existem caminhos diferentes de valoração do letramento, pois os sentidos atribuídos variam interculturalmente e, em certa medida, também variam dentro da cultura.

Há outro aspecto muito importante que permeia a narrativa: ela é um discurso social e culturalmente situado. Conforme Bastos (2005, p. 74), "estudar as estórias ${ }^{5}$ é uma forma de compreender a vida em sociedade". A contação de uma história é, portanto, tratada como um contexto apropriado para apresentar comportamentos cultural e localmente valorizados e esperados, fazendo o que Bruner (2001, p. x) denomina de agenciamento cultural: é através da narrativa "que construímos principalmente uma versão de nós mesmos no mundo, e é por meio de sua narrativa que uma cultura fornece modelos de identidade e agência aos seus membros". Desse modo, ao compartilhar com os seus filhos um livro de gravuras, as mães da comunidade mostram a seus filhos comportamentos e conteúdos culturalmente valorizados na sociedade em que vivem. Knecht (2008) apresenta um exemplo dessa prática na interação entre mãe e filho, contando a história do mesmo livro de gravuras do presente estudo:

\footnotetext{
${ }^{4}$ No presente trabalho, é adotada a nomenclatura evento narrativo para se referir genericamente aos eventos de letramento nos quais a mãe e a criança compartilham um livro de gravuras.

${ }^{5}$ A autora utiliza o termo estória para se referir a "segmentos de fala que, nas entrevistas por ele [Labov] estudadas, remetem a uma sequência de eventos (passados ou possíveis)” (BASTOS, 2005, p. 84).
} 


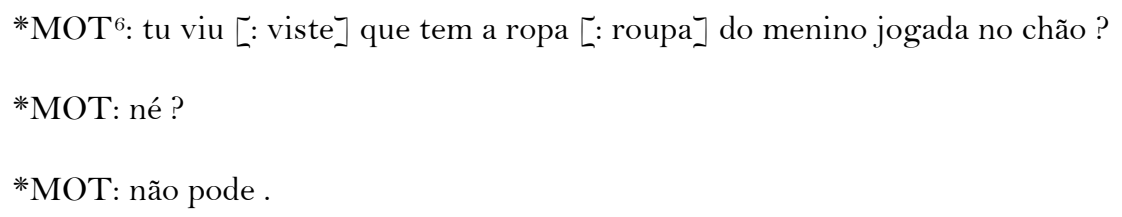

Assim, a mãe ensina a seu filho que não é adequado colocar as roupas no chão, utilizando-se da narrativa para fornecer modelos de comportamento adequado ao seu filho.

\subsection{A narrativa: estrutura, estilos e papéis interacionais}

Contar uma história não se resume a expor uma experiência ou um fato e adequar a narrativa aos moldes da cultura na qual ela está inserida. $\mathrm{O}$ adulto - narrador proficiente - precisa, além disso, ensinar à criança, através da interação, muitos conhecimentos, habilidades e modos de agir, para que ela se torne um (co)narrador autônomo.

Contar uma história requer, então, a habilidade de produzir uma narrativa coerente e reportável, isto é, contável (LABOV, 2001, p. 5). De acordo com o autor, a reportabilidade é relativa à situação social imediata, idade e outros parâmetros culturais. É dessa maneira que o outro, o interlocutor, é capaz de entender a narrativa. Em seu já clássico estudo, Labov e Waletsky (1967, p. 27) definem a narrativa como um método de recapitular experiências passadas, combinando uma sequência de eventos passados, de modo a, em princípio, organizar os enunciados temporalmente na ordem em que os eventos realmente aconteceram.

A organização da narrativa, conforme Bastos (2005, p. 75), é composta por seções optativas e obrigatórias. Bastos (2005, p. 75) caracteriza as seções narrativas de acordo com Labov e Waletzky (1967). As seções resumo, avaliação e coda dão conta da inserção da narrativa numa determinada situação de comunicação. As seções orientação, complicação e resolução configuram a narrativa propriamente dita.

Como postula Bastos (2005, p. 75), é muito comum que a narrativa se inicie com enunciados que a sumarizem, embora facultativamente. O resumo, segundo Labov e Waletzky (1967, p. 22), é um recurso utilizado para despertar o interesse do ouvinte pelo discurso que vem a seguir. A esse resumo inicial seguese uma seção de orientação que, conforme os autores (1967, p. 24), contextualiza o evento a ser relatado, indicando tempo ("quando?"), lugar (“onde?”), pessoas (“quem?”) e circunstâncias ("como?”; "por quê?”). Depois do resumo e da orientação ocorre a história propriamente dita, que consiste na sequência de orações temporalmente ordenadas, a ação complicadora, sem a qual não há narrativa. A estrutura da narrativa, segundo eles (1967, p. 32), tem sequência com a resolução, que corresponde à resposta da pergunta "E finalmente, o que aconteceu?”. A avaliação (1967, p. 25) é outro elemento da narrativa, cuja função é informar sobre a carga dramática ou o clima emocional da narrativa. Essa sinalização do clima emotivo é um fator de reportabilidade da narrativa. Por fim, a coda (1967, p. 33) marca que a narrativa acabou, pois essa fala traz o narrador e o ouvinte (ou co-narrador) de volta ao presente e à conversa. Muitas vezes, essas seções narrativas são desencadeadas por perguntas, ou seja, por meio de uma ou mais perguntas, é possível iniciar, continuar ou terminar uma determinada seção narrativa (ZILLES et al., 2006)

Essa organização temporal - ou o reconhecimento explícito de sua quebra - também está presente nas narrativas de ficção, especialmente aquelas dirigidas a crianças. Mas há, tanto nas narrativas pessoais quanto nas ficcionais, outra característica importante: a relação causal entre os eventos. Ao aprender a contar histórias, as crianças devem aprender a lidar com todos esses aspectos estruturais e pragmáticos. O andaimento (ver acima) é, pois, muito importante para acelerar ou mesmo aprimorar esse desenvolvimento.

Outro aspecto que merece atenção no estudo das narrativas é o fato de que há diferentes estilos narrativos que adultos adotam para contar uma história para seus filhos. Tais estudos também se baseiam no pressuposto de que a criança aprende o discurso narrativo com falantes mais proficientes, através de eventos narrativos, de acordo com a perspectiva sociointeracional. Fivush e Fromhoff (1988), Melzi e Caspe (2005), Zilles et al. (2006), Ávila (2007), Limberger (2008) e Héglan (2009) e Melzi et al. (2011) discutem os estilos narrativos.

\footnotetext{
${ }^{6}$ Utilizamos MOT para indicar a fala da mãe e CHI para indicar a fala da criança. Essas convenções pertencem ao sistema CHAT de transcrição.
} 
Fivush e Fromhoff (1988, p. 340), com o objetivo de examinar como mães estruturam conversas com as crianças, gravaram em áudio conversas de 10 mães com 5 meninas e 5 meninos de 2 anos e meio de idade, residentes em Atlanta, nos EUA. A partir dos dados de Fivush e Fromhoff (1988, p. 343), é possível identificar dois grupos de mães: as mães que adotaram o estilo elaborativo e as mães que adotaram o estilo pouco elaborativo de contar histórias. As mães do primeiro grupo (FIVUSH; FROMHOFF, 1988, p. 351) ofereceram bastante informação sobre os eventos narrados, enquanto as mães do segundo grupo (1988, p. 353) ofereceram pouca informação durante a narrativa.

As mães elaborativas, além de fornecerem bastante informação descritiva sobre os eventos, elaboraram maior quantidade de perguntas do que as mães do segundo grupo, provavelmente por aquelas terem o objetivo de manter a atenção e a interação com a criança e assegurar a continuidade da narrativa. Além disso, essas mães, ao perceberem que a criança não conseguia responder a uma pergunta, tenderam a não oferecer imediatamente a resposta à criança, mas sim a continuar apresentando mais informação sobre o assunto da pergunta, elaborando mais a pergunta, até que a criança conseguisse respondê-la. Nesse grupo, as conversas são mais longas e as mães enriquecem mais a representação dos eventos narrados, disponibilizando às crianças mais pistas para elas observarem as imagens ou acessarem a memória, e, desse modo, conseguirem responder às perguntas direcionadas a elas.

Por outro lado, as outras mães (as pouco elaborativas) tenderam ao estilo por vezes também chamado de reiterativo. Desse modo, elas se engajaram em conversas mais curtas e ofereceram pouca informação sobre os eventos, fazendo poucas perguntas, sendo estas mais repetitivas (nas quais a mãe repete o conteúdo da pergunta anterior) do que elaborativas.

Ávila (2007) investigou, com base em Fivush e Fromhoff (1988), os estilos narrativos entre mães e filhos(as) de três e de cinco anos, residentes em Porto Alegre. O livro compartilhado pelas díades no evento narrativo analisado por Ávila (2007) é o mesmo utilizado para esta pesquisa. Ávila (2007, p. 94) constatou tanto a ocorrência de mães elaborativas quanto de mães pouco elaborativas em ambas as faixas etárias (crianças de 3 e 5 anos) e ambos os gêneros. As mães das crianças mais jovens, em comparação com as mães das crianças maiores, estimularam mais a participação oral de suas crianças e lhes dirigiram uma maior quantidade de perguntas, fornecendo mais andaimento e demonstrando maior preocupação em ensinar suas crianças a contar uma história.

Nesse sentido, os tipos de perguntas que as mães fazem a seus filhos são muito importantes. Conforme Zilles et al. (2006, p. 1), na interação mãe-filho, dependendo do contexto, as perguntas da mãe cumprem diferentes funções. Em princípio, quanto mais perguntas, mais elaborativa a mãe se torna. Diante disso, as autoras (ZILLES et al., 2006, p. 5) classificam as perguntas de acordo com suas funções, conforme se explicita a seguir.

1. Transição entre o mundo "real" (aqui e agora) e o mundo ficcional (narrativo):

a) resumo ou prefácio: sobre o que é a história (MOT: Como é que foi quando o mano nasceu e a gente deu o primeiro banho no mano?);

b) coda: volta à situação presente (MOT: Ah! Que legal, gostei então. Gostei de saber desses dias que eu não tava contigo o que que tu tava fazendo, né?);

2. Mundo ficcional (mundo da história - lá e então):

a) orientação: quem, quando, onde, o quê? (MOT: Quem veio pra cá?);

b) ação complicadora: o que aconteceu? (MOT: O que vocês fizeram durante a viagem?);

c) avaliação: como isto é interessante? (MOT: Ah! Muito bom! E tu gostou?);

d) resolução: o que finalmente aconteceu? (CHI: daí, daí eu fui pra cama e... - MOT: e? CHI: e dormi.);

3. Mundo real - lugar e tempo da enunciação (mundo real - aqui e agora):

a) perguntas de atenção: chamar a atenção da criança; focar sua atenção na atividade de contar história. (MOT: o sapinho fugiu - MOT: tu viu [: viste $]$ ali?); 
b) perguntas sobre vocabulário: perguntas metalinguísticas, sobre palavras ou expressões. (MOT: tu sabe(s) o que significa entalar?);

c) perguntas sobre conhecimento enciclopédico: perguntas relacionadas com conhecimento de mundo. (MOT: abelhinha tem casa?).

Outro aspecto importante na análise das perguntas é a sua forma. As perguntas podem ter várias formas, de acordo com o esquema que segue (ZILLES et al., 2006, p. 5):

a) perguntas abertas: são aquelas cujas respostas expressam proposições derivadas (MOT: E o que nos aconteceu?);

b) perguntas fechadas: duas respostas são possíveis, uma que confirma o conteúdo proposicional expresso na pergunta, a outra que o nega (MOT: Você não foi ver o Bidu?);

c) perguntas alternativas: as respostas são um conjunto de alternativas dadas na própria pergunta (MOT: Isso é uma bota ou uma cobra?);

d) tag-questions: perguntas de confirmação, em que se espera sempre que a resposta reafirme o que está na proposição precedente à indagação feita no final, pela tag-question (Exemplo: MOT: Eu que te contei, né?);

e) perguntas de lacunas: há uma informação a ser fornecida pela criança, correspondente a uma lacuna, uma posição ou espaço em aberto (MOT: O menino encontrou o .... ?);

f) perguntas de continuidade: um pedido de continuidade por parte da mãe ao que está sendo narrado pela criança. E daí, o que mais aconteceu? (MOT: Tá, e daí?).

A partir da utilização dessas perguntas em várias funções e formas, segundo Zilles et al. (2006, p. 6), práticas sociais, crenças e valores culturais são ensinados às crianças. Além disso, ao olhar quem responde às perguntas e como as respectivas respostas se configuram, é possível caracterizar os estilos adotados pelas mães nos eventos narrativos.

Outro aspecto importante no estudo das narrativas, além da elaboração, é a participação. Melzi et al. (2011, p. 1285) apresentam esse conceito: a participação narrativa se refere aos papéis conversacionais adotados por mãe e filho na negociação de quem fornece a informação propriamente narrativa. Algumas mães decidem compartilhar o papel de narrador com os seus filhos (builders - construtores), construindo, assim, a narrativa em conjunto com os seus filhos. Essas mães usam mais perguntas, encorajando a criança a ser conarradora da história. Outras mães criam uma nítida distinção entre os papéis de narrador (tellers narradores) e de audiência. As últimas fornecem a maior parte da informação e assumem, dessa forma, o papel de narrador principal, encorajando a criança a agir com audiência.

Da análise de Héglan (2009) resultam três papéis que a mãe - ou, eventualmente, a criança - pode assumir: o papel de narrador (participante responsável pelo turno até a história terminar), o papel de audiência (ouvinte ou plateia) e o papel de co-narrador, em que a mãe divide com seu filho a responsabilidade de chegar ao fim da história.

Héglan (2009) investigou a co-construção das narrativas por díades mãe e filho de Santa Maria do Herval e de Porto Alegre. A autora focalizou principalmente os papéis interacionais da mãe e do filho. Seus resultados indicam que as díades com crianças de três anos nas duas comunidades requisitam muito mais a participação verbal das crianças. Dessa forma, a mãe propõe para a criança uma co-narração. As mães das crianças de cinco anos não requisitam muito a participação verbal da criança, aproximando-se do papel de narradoras, enquanto as crianças desempenham mais o papel de audiência. Esse resultado é comparável ao de Heath (2001, p. 321), que, ao analisar crianças de mães professoras de classe média numa cidade dos Estados Unidos, constatou que depois dos três anos os adultos desencorajam a criança a desempenhar o até então papel de participação altamente interativo na co-construção de narrativas, e as crianças passam a desempenhar mais o papel de audiência. Essa transformação dos papéis adotados pela mãe e pela criança pode estar relacionada com a menor necessidade de desenvolvimento da ZDP (VYGOTSKY, 1989, p. 97), pois os pais não precisam mais possibilitar a seus filhos a aprendizagem pela participação na contação da história (ZILLES; KNECHT, 2009, p. 45), isto é, não há mais tanto a necessidade de ensinar a contar uma história. Nesse sentido, uma vez alcançada a aprendizagem, os pais retiram ou omitem os andaimes que antes apresentavam. 
Depois desse referencial que fundamenta a nossa análise, passamos agora à seção que explicita a metodologia da pesquisa sobre os estilos narrativos das mães, os papéis interacionais da díade e o uso das línguas nas narrativas.

\section{METODOLOGIA}

Esta seção é dedicada à caracterização dos participantes do estudo, à descrição do contato com eles e também da coleta de dados. Além disso, descrevemos o uso das línguas pelos participantes. Essas descrições são importantes devido à metodologia predominantemente qualitativa adotada no projeto. A seção se encerra com a apresentação do livro utilizado na pesquisa, das convenções de transcrição e dos procedimentos de análise.

\subsection{Participantes}

Selecionamos para este artigo duas díades com meninos de três anos de idade (Joaquim e Ana, Elias e Mirian ${ }^{7}$ ). $\mathrm{O}$ número limitado de participantes se deve à intenção de realizar uma análise detalhada, fornecendo exemplos de práticas que acontecem nas famílias.

As díades residem em Santa Maria do Herval, na Serra Gaúcha. O município se caracteriza por grande parte dos seus habitantes falar português e a variedade do alemão denominada Hunsrückisch (ALTENHOFEN, 1996), língua minoritária principalmente oral ${ }^{8}$. Essa língua é preservada desde a fundação da localidade, em 1835, por imigrantes alemães vindos da região do Hunsrück. No entanto, em virtude do contato com o português, a língua está se modificando gradualmente.

As duas línguas faladas na comunidade são alternadas constantemente pelos participantes da pesquisa. A fala nativa do indivíduo é, então, parte integral de sua história familiar, um sinal de sua identidade local (BLOM; GUMPERZ, 2002, p. 48). Devido à afirmação étnica positiva, muitos pais optam por falar Hunsrückisch com seus filhos. Essa língua faz parte, também, dos eventos de letramento realizados em casa.

Joaquim, um dos meninos participantes deste estudo, tem três anos e mora com os seus pais numa casa localizada no centro do município. Os pais de Joaquim trabalham num supermercado e o deixam durante o dia na creche municipal. Quanto ao letramento na casa de Joaquim, pode-se dizer que os pais incentivam essas práticas, pois o menino tem contato com muitos livros e filmes infantis em casa. Além disso, Joaquim recebe livrinhos na creche para levar para casa. Os pais contam que o menino gosta de comandar os eventos de letramento, uma vez que é ele quem normalmente conta as histórias. Os pais também contam histórias (utilizando as duas línguas). Eles não costumam ler o texto, mas contam a história com base nas gravuras. Os pais de Joaquim falam alemão ${ }^{9} \mathrm{em}$ casa, entre si e com seu filho. Contudo, Ana lamenta que Joaquim não queira mais falar tanto alemão, pois ele tem muito contato com o português na creche. Por ter o desejo de que Joaquim continue falando alemão, a mãe utiliza esta língua constantemente nas interações com ele.

Elias, o outro menino que participou do estudo, também tem três anos e reside com seus pais no centro da cidade. Mirian trabalha no seu salão de beleza, que fica no térreo da sua casa, e o pai, Vilmar, é motorista de ônibus. Enquanto os pais trabalham, uma senhora (que fala pouco português) cuida de Elias juntamente com outras crianças. Ela conta histórias em alemão para as crianças. Além de brincar, os pais conversam bastante (em português e alemão) com a criança. Elias dispõe, ainda, de vários recursos que podem fomentar tanto o letramento quanto a diversão. Tanto a mãe quanto o pai contam histórias, utilizando as duas línguas, mas o pai costuma ler textos em português para a criança. Em uma das nossas visitas, Elias "leu" um livro para nós, ou seja, ele reproduziu em voz alta, fielmente, o texto de um livro infantil, o que

\footnotetext{
${ }^{7}$ Os nomes verdadeiros dos participantes do estudo foram substituídos por pseudônimos, de modo a preservar a sua identidade.

${ }^{8}$ Há esforços na comunidade para tornar o Hunsrückisch também uma língua escrita, liderados pela linguista alemã Ursula Wiesemann. A proposta de Wiesemann (2007) tem alguns efeitos positivos na comunidade, uma vez que os falantes sentem que a sua língua está sendo valorizada. Contudo, a proposta não foi previamente legitimada pelos habitantes da comunidade. Até onde pudemos observar, as ideias tiveram pouca receptividade.

9 Os habitantes da comunidade se referem à língua que falam como "alemão" (Deitsch, como eles falam na comunidade, que corresponde a Deutsch, que é o padrão). Entretanto, “alemão” é um termo muito genérico, uma vez que essa língua tem muitas variedades. Quando reproduzimos a fala dos participantes da pesquisa, utilizamos "alemão", mas quando descrevemos a língua e as narrativas, utilizamos o termo que está consagrado na academia, que define exatamente a variedade em questão, ou seja, Hunsrückisch (ALTENHOFEN, 1996).
} 
demonstra que, além de a criança gostar desse tipo de evento de letramento, ela é habituada a fazê-lo. A mãe de Elias nos contou que ele mistura as duas línguas, mas que as diferencia. O casal passou a falar mais “misturado" com a criança, para que ele não tenha dificuldades e não sofra ao ingressar na escola.

\subsection{Contato com as famílias, observação e registro dos dados}

A equipe do projeto contatou as famílias por telefone e agendou as visitas. Primeiramente, foram apresentados os objetivos e os procedimentos da pesquisa. Além disso, as famílias assinaram o termo de consentimento informado. A equipe visitou a família várias vezes, realizou entrevistas, fez observação participante e redigiu diários de campo, favorecendo a perspectiva êmica na interpretação dos dados, isto é, valorizando também a visão dos agentes que produzem os comportamentos e as ações. As interações aqui analisadas foram gravadas na segunda visita à família. Numa outra visita, foi feita uma entrevista semiestruturada sobre a vida e o letramento na família. Por fim, foi feito um visionamento do vídeo, quando a mãe e a criança falaram sobre as suas impressões em relação à narrativa.

\subsection{Instrumento para coleta: O livro "Frog, where are you?”}

O livro de gravuras desenhadas em preto sobre fundo branco utilizado pela equipe de pesquisa se chama "Frog, where are you?" (MAYER, 1969). Esse livro foi escolhido para permitir comparação dos resultados do projeto maior com os da pesquisadora Gigliana Melzi, da New York University. Além disso, o livro é amplamente utilizado em pesquisas de aquisição da linguagem. Trata-se da história de um menino cujo sapo de estimação fugiu. $\mathrm{O}$ menino sai pela mata, com o seu cachorro, à procura do sapo, fazendo muitas descobertas e passando por vários incidentes. No fim da história, eles descobrem por que o sapo fugira: ele estava com uma fêmea e os seus filhotinhos. No total, há 24 frames, que são 24 gravuras diferentes. $\mathrm{O}$ primeiro frame da narrativa, por exemplo, mostra o menino e o seu cachorro no quarto, olhando o sapo, que está dentro de um vidro. O contexto dos frames é familiar aos participantes da pesquisa e o vocabulário é conhecido (com exceção de uma rena que aparece na floresta, que poucos participantes sabem nomear em Santa Maria do Herval).

\subsection{Transcrição}

A narrativa com base no livro de gravuras descrito acima foi gravada em áudio e vídeo e depois transcrita de acordo com o sistema CHAT (Codes for the Human Analysis of Transcripts), disponível no CHILDES (Child Language Data Exchange System), uma rede internacional para o estudo da Aquisição da Linguagem desenvolvida por MacWhinney (2000) ${ }^{10}$. Além disso, os trechos em Hunsrückisch são fundamentados nas convenções elaboradas pelo grupo ESCRITHU (ALTENHOFEN et al., 2007).

\subsection{Análise}

A análise é predominantemente qualitativa, consiste fundamentalmente numa descrição das narrativas analisadas. Há, contudo, uma pequena análise quantitativa, com números e percentuais apresentados em tabelas, que é feita de modo a traçar um panorama das perguntas feitas nas narrativas (ZILLES et al., 2006) e também a partir disso, depreender o estilo narrativo. Na análise qualitativa, são analisados os papéis desempenhados pela mãe e pela criança durante o evento narrativo, bem como o estilo narrativo adotado (FIVUSH; FROMHOFF, 1988; HEATH, 2001; e HÉGLAN, 2009; MELZI et al., 2011). Isso é analisado levando em consideração não só a gravação da contação da história, mas também a entrevista com a família, o visionamento e as observações realizadas em cada família, favorecendo uma perspectiva êmica de interpretação dos dados. Essa perspectiva é importante porque cada família envolvida no estudo pode ter percepções, práticas e costumes que a diferem das demais, apesar de pertencerem a uma mesma comunidade.

Os dados resultantes da análise são comparados, quando possível, à co-construção de narrativas entre mães e filhos falantes monolíngues de português da mesma comunidade (HÉGLAN, 2009). Isso é possível principalmente porque algumas díades compartilharam o livro de gravuras em alemão e em português, contando a mesma história duas vezes, em visitas realizadas em dias distintos.

${ }^{10}$ Disponibilizamos, em anexo, um resumo das convenções do CHAT, a fim de facilitar a leitura das transcrições. 


\section{RESULTADOS}

Apresentamos inicialmente os resultados da análise quantitativa das interações entre mãe e filho. Logo em seguida, expomos os resultados da análise qualitativa, que é mais ampla justamente por ser mais importante para caracterizar as práticas que ocorrem nas famílias anteriormente apresentadas.

Abaixo, há tabelas com a forma e a função das perguntas feitas pela mãe à criança (adotamos os critérios classificatórios de ZILLES et al., 2006, p. 5). Tais perguntas foram consideradas para determinar quantitativamente o estilo narrativo adotado e os papéis interacionais desempenhados pela díade. A Tabela 1 fornece um panorama geral da forma das perguntas que as mães fazem no decorrer da sua narrativa:

Tabela 1 - Forma das perguntas das mães

\begin{tabular}{ccccccc}
\hline & aberta & fechada & alternativa & lacuna & tag-question & Total \\
\hline Ana e & $8 / 19$ & $3 / 19$ & $\mathrm{O} / 19$ & $\mathrm{O} / 19$ & $8 / 19$ & $\mathbf{1 9}$ \\
Joaquim & $42 \%$ & $16 \%$ & - & - & $42 \%$ & \\
Mirian e & $\mathrm{O} / 9$ & $3 / 9$ & $\mathrm{O} / 9$ & $0 / 9$ & $6 / 9$ & $\mathbf{9}$ \\
Elias & - & $33 \%$ & - & - & $67 \%$ & \\
\hline
\end{tabular}

Frente a tais resultados quantitativos, chama-nos a atenção a grande ocorrência de tag-questions. Há também ocorrência de perguntas abertas e de perguntas fechadas, mas não há perguntas alternativas nem de lacuna. A forma das perguntas não é, portanto, muito variada.

Ao comparamos as duas díades, vemos que Ana fez o dobro de perguntas que Mirian fez. Entretanto, ambas as díades preferiram perguntas que, de certo modo, contêm a resposta: Ana tem 42\% de tag-questions e 16\% de perguntas fechadas, somando $58 \%$. Ana fez mais perguntas abertas a seu filho. Contudo, ele não respondeu a essas perguntas ${ }^{11}$.

Além disso, a transcrição da contação da mãe Ana tem, ao todo, 264 linhas. Esses aspectos nos conduzem a relacionar, de forma preliminar, a narrativa com o estilo elaborativo (FIVUSH; FROMHOFF, 1988).

A outra mãe, Mirian, fez 67\% de tag-questions (por exemplo, MOT: “Eu que te contei, né?”) e 33\% de perguntas fechadas (por exemplo, MOT: "tu gosto(u)?”), o que, em princípio, requer da criança respostas breves e pouco elaborativas.

Além disso, a transcrição da contação da história por Mirian tem 142 linhas. Essas características nos levam a caracterizar, igualmente de forma preliminar, a narrativa de Mirian com o estilo pouco elaborativo na comparação com a atuação da fala da outra mãe.

Complementando a análise quantitativa das narrativas das díades e de suas respectivas perguntas, temos como resultado a tabela 2, que caracteriza as funções das perguntas (conforme ZILLES et al., 2006) que as mães fazem no evento.

Tabela 2 - Função das perguntas das mães

\begin{tabular}{|c|c|c|c|c|c|c|c|c|c|}
\hline & $\begin{array}{l}\text { orien- } \\
\text { tação }\end{array}$ & $\begin{array}{c}\text { ação } \\
\text { compli- } \\
\text { cadora }\end{array}$ & $\begin{array}{l}\text { reso- } \\
\text { lução }\end{array}$ & $\begin{array}{c}\text { avali- } \\
\text { ação }\end{array}$ & coda & $\begin{array}{l}\text { aten- } \\
\text { ção }\end{array}$ & $\begin{array}{c}\text { voca- } \\
\text { bu- } \\
\text { lário } \\
\end{array}$ & $\begin{array}{c}\text { conh. } \\
\text { enciclo- } \\
\text { pédico }\end{array}$ & total \\
\hline Ana e & $9 / 19$ & $2 / 19$ & $\mathrm{O} / 19$ & $4 / 19$ & $2 / 19$ & $2 / 19$ & $\mathrm{O} / 19$ & $\mathrm{O} / 19$ & 19 \\
\hline Joaquim & $49 \% *$ & $10 \%$ & - & $21 \%$ & $10 \%$ & $10 \%$ & - & - & \\
\hline Mirian e & $3 / 9$ & $\mathrm{O} / 9$ & $1 / 9$ & $2 / 9$ & $1 / 9$ & $2 / 9$ & $\mathrm{O} / 9$ & $\mathrm{O} / 9$ & 9 \\
\hline Elias & $34 \%$ & - & $11 \%$ & $22 \%$ & $11 \%$ & $22 \%$ & - & - & \\
\hline
\end{tabular}

*Arredondamos os resultados para ficar mais compatível com o baixo número de ocorrências.

\footnotetext{
${ }^{11}$ É possível constatar no vídeo que o menino não oferece nenhum tipo de resposta às perguntas abertas da mãe. A mãe pergunta e logo oferece a resposta ao seu filho. Em relação às perguntas fechadas, às vezes o menino as responde com meneios de cabeça.
} 
Na tabela 2, podemos verificar que a função das perguntas feitas pelas mães é muito mais variada do que a forma. As perguntas com função de orientação predominam nos dois eventos narrativos em análise: são 49\% no caso de Ana, e 34\% no de Mirian. Ávila (2007, p. 93) verificou que essas perguntas predominam na faixa etária dos três anos. As mães ensinam, assim, as crianças a contar uma história contextualizada. As mães também ajudam as crianças a prestarem atenção às pistas que as gravuras apresentam e a situar o ouvinte, ensinando os seus filhos, por meio do andaimento, a como dar sentido a uma narrativa elaborativa e a como fazer com que o ouvinte a compreenda.

A seguir, apresentamos a análise qualitativa do evento narrativo de cada mãe com seu filho, considerando a análise quantitativa e o referencial teórico apresentado.

\subsection{Ana e Joaquim}

Analisamos aqui a contação da história por Ana em português e Hunsrückisch. Ela contou a história somente uma vez para o seu filho. Solicitamos que ela contasse novamente, mas ela não teve tempo para uma segunda contação. Fizemos somente uma gravação também porque as duas línguas estavam presentes nessa única contação.

Ana conta a história para o seu filho Joaquim ( 3 anos e 3 meses) na sala de estar de sua casa. Nem a criança nem a mãe conheciam a história do sapo, mas a mãe olhou o livro antes de contar. Para ouvir a história, Joaquim está sentado ao lado da mãe, e ela lhe permite o acesso direto ao livro. Joaquim estava com certa expectativa nos esperando para que déssemos o livrinho e a mãe contasse a história para ele. A mãe, por isso, não precisou negociar no início, durante muito tempo, o turno com a criança. Contudo, quando começou efetivamente a contar a história, conforme mostra o excerto ${ }^{12}$ abaixo, Ana teve de interromper o início da narrativa (que corresponde ao resumo, segundo Labov e Waletzky (1967)), para advertir o seu filho (linhas 1 e 5) sobre o uso do livro.

(1)

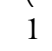

2

3

4

6

7

8

9

10

$14 *$ $* \mathrm{CH}$

$15 *$ MOT:

$16 *$ MOT:

$17 *$ MOT:

$18 *$ MOT:

$19 *$ MOT: ganz zootche, tá?

xxx (es)tava lá dentro.

dentro do vidro.

daí \# um dia tinha uma <coisa estava lá dentro>

[>].

$<$ net vekniege $>[<]$.

$\mathrm{xxx}$.

mhm, <daí $>$ [>].

$<$ daí $>[<]$ uma coisa no vido [: vidro $]$. uma coisa $\mathrm{xxx}$ dentro do vido [: vidro].

tá!

a mãe vai te conta(r).

agola [: agora $]$ eu.

agola [: agora $]$ eu.

a mãe e o pesquisador riem

$\mathrm{xxx}$.

vem cá.

a mãe vai te conta $(r)$.

vamo(s) olha(r) direito essa historinha.

daí tu vai(s) ajuda(r) a mamãe.

eu e tu vamo(s) conta(r).

\footnotetext{
12 Os turnos em Hunsrückisch são traduzidos para o português. A tradução sempre está em itálico e se localiza ao lado do turno em alemão correspondente.
}

toma cuidado

não amassa 
Ao fazer isso, a mãe ensina o bom manuseio do livro. Isso é comum na comunidade - as crianças têm que saber utilizar um livro e tratar bem dele, para que não os estraguem (principalmente quando se trata dos livros dos outros e os da escola também). Dessa forma Ana faz, por meio da narrativa, o que Bruner (2001) denomina de agenciamento cultural.

Mostrando-se interessada nas gravuras, a criança participa da construção da história, o que leva a mãe a interromper a seção de orientação e negociar com Joaquim sobre quem conta a história e em que condições. A princípio, havíamos pedido que a mãe contasse a história para a criança e, pelo que se pode perceber nas linhas 11,16 e 18, a mãe estava preocupada com isso. Todavia, como o filho queria muito participar, como podemos verificar nas linhas 12 e 13, ela propõe nas últimas linhas do excerto acima, uma co-narração. Segundo Héglan (2009, p. 122) e Heath (2001, p. 321), as mães das crianças de três anos requisitam, como Ana, com frequência a participação verbal das crianças, buscando uma co-narração.

Ana fornece bastante andaimento (WOOD; BRUNER; ROSS, 1976, p. 89) para Joaquim. O fato de ela ter proposto uma co-narração da história com a criança já caracteriza um andaime fornecido, pois, ao fazê-lo, ela interessou e engajou o menino na resolução da tarefa - contar a história. Além disso, ao fazer junto com ele, facilita-lhe o processo. Dessa forma, os papéis desempenhados pelos participantes são ativa e explicitamente co-construídos (ZILLES; KNECHT, 2009).

A criança oferece poucas contribuições verbais para a história. Depois do turno 16 do primeiro excerto $(A$ mãe vai te contar), Joaquim desempenha mais o papel de audiência (HÉGLAN, 2009; MELZI et al., 2011) da história, pois só responde verbalmente às perguntas da mãe duas vezes e faz poucas perguntas e/ou declarações. Mesmo assim, ele está engajado ouvindo a história. A mãe nos afirmou que, quando a criança decide contar uma história, a mãe e o pai somente a ouvem e vice-versa. Esse costume pode ter colaborado para determinar os papéis desempenhados pela mãe e pela criança no evento analisado, pois elas estão habituadas a fazer desse modo.

Quanto ao uso das línguas, a mãe nos disse que conversa com a criança em alemão, pois ela crê que é nessa idade que a criança consegue aprender melhor. Joaquim entende alemão, mas fala pouco. Por isso, ela faz constantes alternâncias de código para dialogar com a criança. Além disso, como no seguinte excerto, na orientação da narrativa (LABOV; WALETZKY, 1967), ela profere um determinado enunciado em alemão (4) e o reformula em português (5), podendo, dessa forma, assegurar mais facilmente a compreensão da criança.

(2)

1 *MOT: olha aqui, aqui tem um mato.

2 *MOT: $\quad$ ich denke, jetz gehn sie in die Floresta rinn.

3 *MOT: $\quad$ suche wo de Sapo rum mecht sinn.

4 *MOT: $\quad$ wo mecht de Sapo rum hingan sinn?

5 *MOT: $\quad$ aonde será que foi o sapo?

Além desse aspecto, outro chama atenção no evento narrativo em análise, a utilização do baby talk, que enaltece a carga de afetividade da interação (ALTENHOFEN, 2002, p. 8). A mãe utiliza muitos diminutivos para conversar com a criança, tanto em alemão como em português: zootche (delicadinho), historinha, Glosche (vidrinho), Wawau (vavau - cachorrinho), amiguinhos, Quartoche (quartinho), caminha, nanache mache (fazer nana - dormir), Meninoche (menininho), Sapatoche (sapatinho), entre muitos outros. Alguns exemplos de baby talk em alemão integram elementos do alemão à base do português, como em Meninoche e Sapatoche (-che é sufixo diminutivo em Hunsrückisch, que corresponde ao sufixo do alemão padrão -chen).

Outra característica interessante em relação ao uso das línguas é o fato de que a mãe, ao fazer discurso reportado, alterna o código sempre para o português. No excerto abaixo, Ana, quando faz a voz do menino (linhas 2, 4 e 5), muda imediatamente de língua, que era alemão e passa a ser português.

(3)

1 *MOT: $\quad$ hon gesucht unn geruft + " /.

2 *MOT: $\quad+$ " sapo!

3 *MOT: ó, de menino geruft $+" /$.

procuraram e chamaram

o menino chamou 


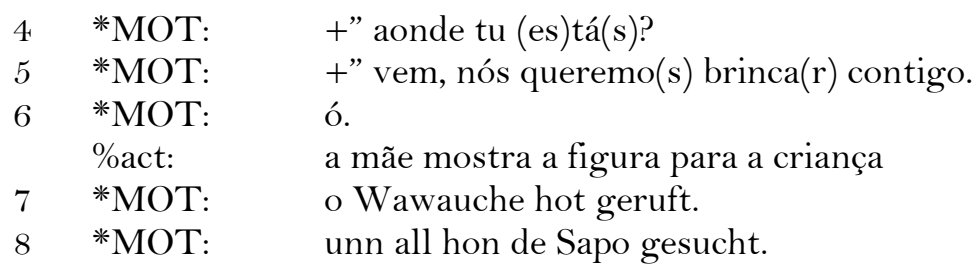

o vavauzinho chamou
e todos procuraram o sapo.

Quando a mãe faz isso, ao mudar de código, ela sinaliza mudança também na relação que ela estabelece com a criança e com a história (antes ela a mãe era a narradora, que estava contando a história para a criança e, agora, ela passa a ser a mãe imitando a voz do menino). Essa alternância de códigos implica uma atitude avaliativa por parte da mãe (ZILLES; FARACO, 2006). Uma possibilidade interpretativa pode estar relacionada com a seguinte suposição: como há somente livros em português na comunidade, e essa língua é fortemente ligada ao letramento, a mãe conecta a fala do menino (por ele ser personagem da história) com o texto escrito em português. Além disso, a mãe muda constantemente o código, fornece detalhes relevantes das figuras e reformula as perguntas, conforme podemos verificar no excerto 4, que também está inserido na orientação da narrativa.

(4)
*MOT:

*MOT:

*MOT:

*MOT:

*MOT:

*MOT:

*MOT:

*MOT: daí o Meninoche acordo(u).

olha aqui.

O sol entro(u) na janela dele.

acordo(u) o Meninoche.

unn de Wawau [: cachorro]. $\quad$ o o vavau.

do hon sie geguckt.

ué, onde (es)tá o sapo?

aonde (es)tá o nosso amiguinho sapo?

\section{Menininho}

então eles olharam

Em suma, a quantidade e a qualidade das perguntas e sua reformulação, o discurso reportado, o andaimento constante e também a extensão do evento narrativo (a transcrição tem ao todo 264 linhas) caracterizam essa mãe como elaborativa (FIVUSH; FROMHOFF, 1988). A mãe nos relatou que o pai conta mais histórias para Joaquim, mas que, quando ela conta, não costuma ler as histórias com texto, mas as conta com base nas suas próprias palavras, utilizando sempre as duas línguas, como faz na narrativa em análise. O costume de "inventar" histórias com base nos livros de gravuras poderia ter contribuído para a adoção, na narrativa em análise, do estilo elaborativo, uma vez que ela já está acostumada a contar/ouvir histórias baseadas em livros de gravuras e a partir da não-leitura, a mãe tem mais liberdade para fazer perguntas, comentários e declarações.

\subsection{Mirian e Elias}

Mirian e Elias interagiram com o livro de gravuras no sofá da sala de televisão da sua casa. A história já era conhecida pela díade, pois a mãe já a tinha contado para a criança, mas em português, com alternâncias de código para o alemão, iniciadas pela criança. Essas alternâncias foram comentadas pela mãe, que as atribuiu ao fato de que o alemão era a língua usada predominantemente pelo menino.

Antes da gravação da narrativa, o pai, a mãe e o filho estavam assistindo a um desenho animado na televisão. Quando a mãe resolveu começar a contar a história para a criança, ela teve que desenvolver uma negociação com a criança sobre a televisão ficar ou não ligada durante o evento narrativo. Elias não queria que a desligassem. Por isso, foi necessário intervir e pedir que a desligassem, pois isso poderia atrapalhar o evento narrativo e, em especial, seu registro em áudio e vídeo. Essa interrupção das atividades cotidianas durante a coleta de dados é o resultado da situação na qual o pesquisador visita a casa da família e solicita que eles interajam como sempre costumam fazer. Para que o evento fosse mais natural, seria mais adequado deixar a câmera na casa da família. Contudo, a interrupção não foi tão problemática, porque os pais de Elias disseram que também interrompem as atividades que estão fazendo para contar histórias, quando Elias manifesta vontade de interagir em tal evento de letramento.

No início da história, a mãe desenvolve uma seção de orientação, apresentando as personagens (linha 1) e o cenário (linha 2) e, quando a mãe fala o nome do sapo, a criança estabelece uma relação intertextual com a canção $O$ sapo não lava o pé e a canta (linha 3): 
(5)

1 *MOT:

$2 *$ MOT:

$3 \quad * \mathrm{CHI}$ :

4 *MOT:

$5 \quad * \mathrm{CHI}$ :

6 *MOT:

*act:

$7 \quad * \mathrm{CHI}$ :

$8 \quad *$ MOT:

$9 \quad * \mathrm{CHI}$ :

10 *MOT:

$11 *$ MOT: do is de Menino \# unn de Cachorro unn de Sapo.

huckt in Vidro $<$ de $>[/]<$ de $>$ Sapo ó.

é o sapo.

é o <sapo $>$ [>]!

$<$ o sapo $>[<]$ não lava o pé, ele não lava

porque não que(r).

jo \# de Sapo is es \# <jo $>$ [>].

a mãe vira já a página

$<$ ele mora $>[<]$ lá na lagoa porque não que(r) [: não lava o pé porque não quer $]$.

$<$ ó aqui $>[>]$.

$<$ mas que $>[<]$ chulé!

é!

é aqui tut de schlofe de Menino . ali tem o menino e o cachorro e o sapo

está sentado no vidro o o sapo ó.

sim o sapo é esse sim

o menino está dormindo

Esse excerto demonstra que uma história não precisa ficar limitada ao conteúdo proposto no livro, a criança ou a mãe pode estabelecer conexões com experiências passadas, tornando o evento narrativo mais rico para a criança. Na linha 6 , vemos que a mãe aceita a contribuição da criança, mas logo a seguir vira a página (linha 7), gesto com o qual procura retomar a contação da história. A criança, contudo, não a acompanha e continua cantando a canção que iniciara antes (linha 5). Há nova tentativa da mãe de retomar a história (linha 8), mas a criança não se alinha às ações da mãe e canta a canção até o final, quando a mãe consegue retomar a contação (linha 11 acima).

Durante o evento narrativo, Elias está sentado ao lado da mãe. A mãe mostra as figuras e permite que o filho tenha acesso direto ao livro e que vire a página, conferindo-lhe o poder de conduzir com ela o andamento da história. Elias sempre pode ver as figuras, pois a mãe está ao seu lado; pode, inclusive, se demorar por mais tempo numa ou noutra página, caso demonstre interesse em fazê-lo. Além disso, como pudemos perceber no excerto anteriormente apresentado, há, algumas vezes, uma disputa pela palavra. A criança, como deseja também participar verbalmente do evento narrativo, profere turnos simultâneos aos da mãe, como, por exemplo, nas linhas 4 e 5, 6 e 7 e 8 e 9 (conforme sinalizado na transcrição por meio de [>], primeiro turno da fala simultânea, e $[<]$, segundo turno da fala simultânea).

A criança faz várias perguntas durante a história. Ela faz principalmente perguntas que demonstram a sua curiosidade e o seu engajamento na história, como: "Unn do?" (E aqui?); "E aqui?"; "Was macht de do?" $(O$ que ele está fazendo aqui?); "Wo is de Menino?” (Onde está o menino?). Diante dessas perguntas, a mãe as responde e elas servem para que a história prossiga, numa construção conjunta da narrativa.

Até os três anos, segundo Heath (2001, p. 321), as crianças da comunidade estudada podem ter um papel altamente interativo na co-construção de narrativas. Para a narrativa em análise, pode-se pensar, portanto, em co-narração da história, tal como Héglan (2009) e Zilles, Héglan e Limberger (2007) observaram nas díades com crianças de 3 anos na mesma comunidade. Por meio das perguntas, como abaixo nas linhas 1 e 2, Elias colabora para que a história prossiga:

(6)

$\begin{array}{ll}1 & * \mathrm{CHI}: \\ 2 & * \mathrm{CHI}: \\ 3 & * \mathrm{MOT}: \\ 4 & * \mathrm{CHI}: \\ 5 & * \mathrm{MOT}:\end{array}$

unn do?

was macht de do? do hucke die Sapochie!

$<$ do hucka $>$ [>].

$<$ hinnich $>[<]$ de Árvore!

\author{
e aqui? \\ o que ele está fazendo aqui? \\ ali estão os sapinhos! \\ ali estão. \\ atrás da árvore!
}

Essas perguntas e comentários da criança durante a história não devem ser considerados como interrupções no evento narrativo. As manifestações da criança demonstram que ela está engajada na construção conjunta história, compreendendo o que está sendo discutido. Isso se evidencia mais claramente no fim do evento, na seção da coda (LABOV; WALETZKY, 1967), quando a mãe pergunta à criança se ela gostou da história (na linha 3 do excerto abaixo): 
(7) jetz is es aus!

jo.

a criança fecha o livro

tu gosto(u)?

woll ma noch mo \&mach [//] woll ma noch mo gucke?

noch mo gucke?

mea hon jetz schon geguck.

a criança folheia o livro agora acabou!

sim.

vamos fazer mais uma vez vamos ver mais uma vez?

ver mais uma vez?

nós já olhamos agora

Quando a mãe pergunta (linha 3), Elias deve avaliar a história como um todo. Para tanto, ele precisa ter compreendido o que foi contado, o que, efetivamente, foi demonstrado por ele por meio do seu engajamento. No fim do evento narrativo, Elias também pede para novamente olhar a historinha (linha 4 do excerto 6 ), mas a mãe, devido a compromissos, não podia fazer isso com ele naquele momento.

A mãe adota o estilo pouco elaborativo para contar a história (como já fizera antes ao contar a mesma história em português). Ela não faz muitas perguntas e, na sua maioria (seis perguntas), as perguntas têm a forma tag. Além disso, a função das perguntas não foi tão variada. O evento narrativo não foi tão longo quanto o de outras mães, cujo estilo adotado é elaborativo. Contudo, a mãe aceitou as intervenções e considerações da criança, feitas principalmente sob a forma de perguntas, e as aproveitou para que a história prosseguisse, mas sem desenvolvê-las ou detalhá-las, como faria se adotasse um estilo elaborativo. A mãe, basicamente, aceitou a sua canção, as suas perguntas e os seus comentários, sem, contudo, enriquecê-los ou aprofundálos. Isso pode ter acarretado, então, o fato de a criança desempenhar o papel de co-narradora (HÉGLAN, 2009).

Quanto ao uso das línguas, como é notório nos excertos aqui apresentados, a mãe e a criança fazem, constantemente, alternâncias de código. Isso se deve ao fato de que, naquela casa, isso ser perfeitamente prática cotidiana. Além disso, pode-se entender que o Hunsrückisch tem um valor afetivo naquela família (cf. PARADIS, GENESSE e CARGO, 2011), porque é a língua de uso familiar, a língua da infância e da comunidade. Durante as visitas e as gravações, verificamos que a criança sabe falar as duas línguas e ela alterna essas línguas sempre nas suas interações. No evento narrativo, a mãe introduz palavras como menino, cachorro, sapo, vidro, chinelos, bota, roupa, camelo, árvore, entre outras, em português. Por meio dessas palavras, a mãe nomeia objetos do cenário e os personagens, demonstrando a utilização conjunta das duas línguas, o que é característico do contexto bilíngue investigado. Além disso, quando a criança pergunta em português, a mãe manifesta reciprocidade, ou seja, responde nessa língua, mas logo passa para o alemão. Assim, a mãe aceita a língua escolhida pela criança, fornecendo-lhe andaimento.

\section{CONSIDERAÇÕES FINAIS}

A narrativa, como foi possível verificar por meio da pesquisa, realmente oferece muitas possibilidades à criança. Ao contar uma história, a mãe, além de ensinar padrões culturais, valores e costumes da comunidade (MELZI, 2000; BRUNER, 2001.), promove o desenvolvimento do discurso narrativo (PERRONI, 1992).

O presente estudo teve como propósito uma investigação sobre a co-construção da narrativa bilíngue entre mãe e seu filho de três anos enquanto compartilham o livro de gravuras intitulado "Frog, where are you?" (MAYER, 1969).

Sobre o estilo narrativo adotado pelas mães (FIVUSH; FROMHOFF, 1988), a mãe Ana adotou o estilo elaborativo, já que fez mais perguntas, estendeu mais a sua narrativa e utilizou mais recursos estilísticos para contar a história para Joaquim. Mirian, contudo, adotou o estilo pouco elaborativo. Poder-se-ia, talvez, atribuir essa escolha ao fato de Mirian já ter contado anteriormente a história, ainda que o tivesse feito, a nosso pedido, predominantemente em português. Nessa ocasião, chamou-nos atenção as participações da criança em alemão, mesmo que a mãe se mantivesse usando português. Por isso, acreditamos que seria interessante examinar uma segunda contação, mas em alemão. Outro aspecto que merece destaque é que, no caso desta família, foi-nos relatado que era mais o pai do que a mãe o adulto que usualmente contava 
histórias e brincava ou passeava com a criança. Pareceu-nos que essa mãe estava, de fato, pouco à vontade no papel de narradora. O que merece destaque, no entanto, é que observamos a adoção dos dois estilos narrativos, distribuição que vem ao encontro dos resultados de Ávila (2007).

Quanto aos papéis interacionais que as crianças adotam, Joaquim adota o papel de audiência, talvez por estar acostumado a adotar esse papel na creche e também em casa. Todavia, a mãe o incentiva, de modo que ele passasse a agir como co-narrador da história em alguns momentos. Elias, ao contrário, age como conarrador tanto na história contada predominantemente em português quanto na história contada em alemão. Tais dados se relacionam com os dados das crianças de três anos cujas mães contaram a história em português na mesma comunidade, buscando, em geral, uma co-narração da história (HÉGLAN, 2009).

Quanto ao uso das línguas, há características interessantes nos eventos narrativos. Ana, ao contar a história para Joaquim, faz alternâncias de código para o português ao fazer discurso reportado. Mirian utiliza palavras isoladas em português na contação da história em alemão (como no excerto 6). Além disso, ambas as mães utilizam baby talk para falar com seus filhos. As mães fornecem, ainda, andaimento para as crianças, tanto na aceitação das línguas quanto no auxílio às crianças para que elas contassem a história.

Tais resultados são importantes para conhecermos algumas práticas adotadas por mães e seus filhos no que tange à narrativa, mas também devido à sua relação com as práticas escolares. Segundo Heath (2001, p. 336), as orientações de letramento familiar próximas das praticadas na escola têm como resultado crianças com sucesso escolar. É importante, então, que habilidades que foram ensinadas às crianças em práticas de socialização linguística familiares e a exploração de valores baseados na cultura sejam conhecidas pelos professores. Nesse sentido, pode-se considerar a aplicação do que foi abordado neste trabalho em sala de aula.

Sugerimos que as professoras da comunidade poderiam contar histórias para seus alunos da comunidade ${ }^{13}$ empregando recursos que as mães utilizam em casa: discurso reportado em alemão; diminutivos em alemão; contação em português e explicação em alemão (ou vice-versa), contação de história somente em alemão; e alternância de papéis interacionais e de código. $\mathrm{O}$ uso de tais recursos em nosso estudo se refere a um grupo restrito de mães, mas é possível supor que não sejam casos isolados e que outras mães com condições semelhantes na comunidade contem histórias de forma similar. Destacamos, pois, que, ao contrário do que se supunha, o uso de alemão em eventos de letramento não parece ser anormal nas famílias da comunidade.

Propomos, neste artigo, uma análise mais qualitativa. Por isso, os resultados aqui apresentados não devem ser considerados como uma generalização, mas como uma descrição de exemplos do que acontece na coconstrução de narrativas bilíngues entre mães e filhos de três anos. Além disso, uma descrição só estaria completa se fossem analisados também outros contextos de interação (relatos de experiência pessoal e contação de uma história com texto escrito, principalmente).

Outra limitação deste trabalho é a situação de pesquisa, isto é, a interação entre mães e filhos não ocorreu em eventos espontâneos, mas em eventos resultantes de solicitação da equipe de pesquisa. Por esse motivo, não sabemos como a família age exatamente sem a presença de câmera e de pesquisadores. Para que o evento fosse mais natural, seria mais adequado deixar a câmera na casa da família, o que implicaria, no entanto, a disponibilidade de mais recursos, o que era inviável no momento do trabalho de campo. Nesse sentido, um estudo mais sistemático seria interessante. Gigliana Melzi, numa visita à Unisinos, em maio de 2008, elogiou a iniciativa de analisar falantes bilíngues contando uma história. Segundo ela, há poucas destas iniciativas no mundo.

Diante dos resultados alcançados, acreditamos que nós, enquanto professores dos diversos níveis de ensino, em comunidades bilíngues como a deste estudo, devemos valorizar o que as crianças trazem de casa, isto é, o seu bilinguismo, a sua identidade, a sua afetividade, o seu modo de conversar e interagir. Para tanto, devemos buscar conhecer o que as crianças já sabem. Assim, possibilitaríamos uma minimização das dificuldades e, no caso das crianças pequenas, um ingresso mais tranquilo na escola (HEATH, 2001), aproximando as atividades de aula às práticas familiares.

\footnotetext{
13 A sugestão foi dada com base na experiência de uma professora da localidade, que contava histórias para crianças bilíngues (falantes de Hunsrückisch e de português) e monolíngues (falantes de Hunsrückisch ou falantes de português). Ela nos disse que contava histórias alternando o código, para que todas as crianças compreendessem a história. Assim, todas as crianças entravam em contato com as duas línguas.
} 


\section{REFERÊNCIAS}

ALTENHOFEN, C. Hunsrückisch in Rio Grande do Sul: Ein Beitrag zur Beschreibung einer deutschbrasilianischen Dialektvarietät im Kontakt mit dem Portugiesischen. Stuttgart: Steiner, 1996.

O conceito de língua materna e suas implicações para o estudo do bilinguismo (alemão-português). Martius-Staden-Jahrbuch, v. 49, p. 141-161, 2002.

ALTENHOFEN, Cléo Vilson; FREY, Jaqueline. Das bresilionische Deitsch unn die deitsche Bresilioner: en Hunsrickisch Red fo die Sprocherechte. Revista Contingentia, v. 1, p. 39-50, 2006.

ALTENHOFEN, C.; FREY, J.; KÄFER, M.; NAUMANN, G.; SPINASSÉ, K. Fundamentos para uma escrita do Hunsrückisch falado no Brasil. Revista Contingentia, v. 2, p.73-87, 2007.

ÁVILA, A. S. Estilos narrativos de mães ao compartilharem livro de gravuras com seus filhos. Dissertação (Mestrado em Linguística Aplicada) - Programa de Pós-Graduação em Linguística Aplicada da Universidade do Vale do Rio dos Sinos, São Leopoldo, 2007.

BASTOS, L. C. Contando histórias em contextos espontâneos e institucionais - uma introdução ao estudo da narrativa. Calidoscópio, v. 3, n. 2, p. 74-87, 2005.

BLOM, J.; GUMPERZ, J. J. O significado social da estrutura linguística: alternância de códigos na Noruega. Trad. de P. M. Garcez e J. P. de Araújo. In: RIBEIRO, B. T.; GARCEZ, P. (Orgs.).

Sociolinguística interacional. 2. ed. São Paulo: Edições Loyola, 2002. p. 45-84.

BREUNIG, C. A alternância de código como pedagogia culturalmente sensível nos eventos de letramento em contexto multilíngue. Dissertação (Mestrado em Letras) - Programa de Pós-Graduação em Letras da UFRGS, Porto Alegre, 2005.

BRUNER, J. A cultura da educação. Porto Alegre: Artmed, 2001.

CLARK, H. O uso da linguagem. Tradução de Nelson de Oliveira Azevedo e Pedro M. Garcez. In: GARCEZ, Pedro (Org.). Cadernos de Tradução do Instituto de Letras da UFRGS, v. 9, p. 49-71, 2000.

FIVUSH, R.; FROMHOFF, F. Style and structure in mother-child conversations about the past. Discourse Processes, v. 11, p. 337-355, 1988.

GARCEZ P.; OSTERMANN, A. C. Glossário conciso de Sociolinguística Interacional. In: RIBEIRO, Branca Telles; GARCEZ, P. Sociolinguística Interacional. 2. ed. Porto Alegre: Loyola, 2002. p. 257-264.

HADEN. C.A. Joint encoding and joint reminiscing implications for young children's understanding and remembering of personal experiences. In: FIVUSH, R.; HADEN, C. A. (Eds.). Autobiographical memory and the construction of a narrative self. Mahwah, New Jersey: Lawrence Erlbaum Associates Publishers, 2003. p. 49-69.

HEATH, S. What no bedtime story means: narrative skills at home and school. In: DURANTI, Alexandro. Linguistic anthropology: a reader. Oxford: Blackwell Publishing, 2001, p. 318-342.

HÉGLAN, H. A co-construção de narrativas na interação entre mães e filhos de 3 e 5 anos em uma comunidade teuto-brasileira. Dissertação (Mestrado em Letras) - Programa de Pós-Graduação em Letras da UFRGS, Porto Alegre, 2009.

ILUZ-COHEN, P.; WALTERS, J. Telling stories in two languages: narratives of bilingual preschool children with typical and impaired language. Bilingualism: language and cognition, v. 15, n. 1, p. 58-74, 2012.

JACOBY, S.; OCHS, E. Co-construction: an introduction. Research on language and social interaction, v. $28, \mathrm{n}$. 3, p. 171-183, 1995.

KNECHT, F. O agenciamento cultural nas narrativas entre mães e filhos de Porto Alegre e Santa Maria do Herval. Comunicação apresentada na Mostra de Iniciação Científica Unisinos. São Leopoldo: Unisinos, 2008.

LABOV, W. Uncovering the event structure of narrative. Georgetown: Georgetown University Press, 2001.

LABOV, W.; WALETSKY, J. Narrative analysis: oral versions of personal experience. In: HELM, J. (Ed.). Essays on the verbal and visual arts. Seattle, WA: University of Washington Press, 1967. 
LIMBERGER, B. A co-construção de narrativas entre mães e filhos falantes de alemão numa comunidade teuto-brasileira. Graduação (Trabalho de conclusão de curso em Letras) - Universidade do Vale do Rio dos Sinos, São Leopoldo, 2008.

MAYER, M. Frog, where are you? New York: Dial Press, 1969.

MACWHINNEY, B. The CHILDES Project: Tools for Analyzing Talk. $3^{\text {rd }}$ Edition. Mahwah, NJ: Lawrence Erlbaum Associates, 2000.

MELZI, G. Cultural variations in the construction of personal narratives: Central American and EuropeanAmerican mothers' elicitation discourse. Discourse Processes, v. 30, n. 2, p. 153-177, 2000.

MELZI, G.; CASPE, M. Variations in maternal narrative styles during book reading interactions. Narrative inquiry, v. 15, n. 1, p. 101-125, 2005.

MELZI, G.; SCHICK, A. e KENNEDY, J. L. Narrative elaboration and participation: two dimensions of maternal elicitation style. Child development, v. 82, n. 4, p.1282-1296, 2011.

PARADIS, J.; GENESSE, F.; CRAGO, M. Dual language development disorders. Baltimore: Brookes, 2011.

PERRONI, M. C. Desenvolvimento do discurso narrativo. São Paulo: Martins Fontes, 1992.

SCARPA, E. M. Aquisição da Linguagem. In: MUSSALIM, F.; BENTES, A. C. (Orgs.). Introdução à Linguística. São Paulo, Cortez, 2001.

SCHNACK, C. Baby talk: uma fala de adulto direcionada à criança. Que criança? Que adulto? Calidoscópio, v. 5, n. 2, p. 115-124, 2005.

VYGOTSKY, L. S. A formação social da mente: o desenvolvimento dos processos psicológicos superiores. 3. ed. São Paulo: Martins Fontes, 1989.

WIESEMANN, U. Contribuição ao desenvolvimento de uma ortografia da língua Hunsrik falada na América do Sul. Cuiabá: Associação Internacional de Lingüística-SIL Brasil, 2008.

WOOD, D.; BRUNER, J.; ROSS, G. The role of tutoring in problem solving. Journal child Psychology and Psychiatry, v. 17, p. 89-100, 1976.

ZILLES, A. M. S.; FARACO, C. A. As tarefas da sociolingüística no Brasil: balanço e perspectivas. In: GORSKI, E. M.; COELHO, I. L.. (Orgs.). Sociolingüística e ensino: contribuições para a formação do professor de língua. Florianópolis: Editora da UFSC, 2006.

ZILLES, A. M. S.; HÉGLAN, H.; LIMBERGER, B. A avaliação na co-construção de narrativas a partir de um livro de gravuras por mães e suas filhas de três anos. Desenredo, v. 3, n. 2, p.151-181, 2007.

ZILLES, A. M. S.; KNECHT, F.; ÁVILA, A.; HÉGLAN, H. A co-construção de narrativas em díades mãecriança: forma e função das perguntas. Trabalho apresentado no $7^{\circ}$ Encontro Nacional de Aquisição da Linguagem - ENAL. Porto Alegre, PUC-RS, 2006.

ZILLES, A. M. S.; KNECHT, F. “Vamos contar, eu e tu?”: andaimento e cultura na co-construção de uma narrativa infantil. Organon, Porto Alegre, v. 46, p. 47-70, 2009.

\section{ANEXO - CONVENÇÕES DE TRANSCRIÇÃO DO CHAT}

\begin{tabular}{|c|c|c|}
\hline *MOT: & (asterisco, MÃE e dois pontos) & Fala da mãe \\
\hline *CHI: & (asterisco, CRI e dois pontos) & Fala da criança \\
\hline *PES: & (asterisco, PES e dois pontos) & Fala do pesquisador \\
\hline . & (ponto final) & Entonação descendente \\
\hline$?$ & (ponto de interrogação) & Entonação ascendente \\
\hline$\#$ & (sustenido) & Pausa \\
\hline - & (hífen) & Marca de corte abrupto \\
\hline \&palav & ("e" comercial e palavra incompleta) & Palavra não pronunciada até o seu final \\
\hline$+/ ”$ & $\begin{array}{c}\text { (sinal de mais, barra para passar a } \\
\text { voz ao personagem) }\end{array}$ & Início da voz da personagem \\
\hline +" onde você está? & (sinal de mais e aspas antes da fala da & Indicação de discurso reportado \\
\hline
\end{tabular}




\begin{tabular}{|c|c|c|}
\hline & personagem) & \\
\hline [: palavra $]$ & $\begin{array}{c}\text { (dois pontos e palavra entre } \\
\text { colchetes) }\end{array}$ & Palavra ou expressão na língua padrão \\
\hline$<$ palavra $>$ & $\begin{array}{l}\text { (sinais de menor do que e maior do } \\
\text { que) }\end{array}$ & Seleção de determinada palavra \\
\hline$[>]$ & (sinal maior que entre colchetes) & Fala simultânea (primeiro turno) \\
\hline$[<]$ & (sinal menor que entre colchetes) & Fala simultânea (segundo turno) \\
\hline $\operatorname{ve}(r)$ & $\begin{array}{c}\text { (letras que complementam a palavra } \\
\text { no padrão entre parênteses) }\end{array}$ & Padrão da palavra \\
\hline $\mathbf{a} @ \mathbf{i}$ & (arrouba entre a interjeição) & Interjeição \\
\hline $\mathbf{a u}+\mathbf{a u}+\mathbf{a u}$ & (sinal de mais entre as partículas) & Onomatopeia \\
\hline \%com & (sinal de porcentagem e com) & Comentário do transcritor \\
\hline \%act & (sinal de porcentagem e act) & Ação do participante da interação \\
\hline \%par & (sinal de porcentagem e par) & Atitude paralinguística \\
\hline$[/]$ & (barra entre colchetes) & Repetição de palavra ou expressão \\
\hline$[/ /]$ & (duas barras entre colchetes) & $\begin{array}{l}\text { Correção de palavra ou expressão pelo } \\
\text { narrador }\end{array}$ \\
\hline $\mathbf{x x}$ & (dois Xs) & Uma palavra não compreendida \\
\hline $\mathbf{x x x}$ & (três Xs) & $\begin{array}{l}\text { Duas ou mais palavras não } \\
\text { compreendidas }\end{array}$ \\
\hline u@ih! & (arrouba entre a palavra) & Interjeição \\
\hline „,né? & (duas vírgulas e palavra) & Tag question \\
\hline$+\ldots$ & (sinal de mais e reticências) & Perguntas de continuidade \\
\hline
\end{tabular}

Recebido em 29/01/13. Aprovado em 09/o3/13. 